\title{
Pelatihan Kewirausahaan dan Peningkatan Kualitas Manajemen dan Tata Kelola Keuangan Bagi Pelaku UMKM di Lingkungan PKK Tiban Global Batam
}

\author{
Mohamad Trio Febriyantoro ${ }^{1}$ \\ Universitas Universal, mtriofeb@gmail.com \\ Ibnu Harris ${ }^{2}$ \\ Universitas Universal, ibnu.harris@gmail.com \\ Didi Sundiman ${ }^{3}$ \\ Universitas Universal, sundiman.didi@gmail.com \\ MN Reza Pradana ${ }^{4}$ \\ Universitas Universal, rezapradana7@gmail.com \\ Emi Lestari ${ }^{5}$ \\ Universitas Universal, emi.lestari@uvers.ac.id
}

\begin{abstract}
ABSTRAK
Dalam rangka mendukung program pemerintah dalam menciptakan wirausaha dan mendukung peningkatan kualitas para UMKM maka prodi Manajemen akan memberikan pelatihan kepada para UMKM yang berada di lingkungan PKK Tiban Global, Pelatihan ini bertujuan meningkatkan kemampuan berwirausaha dan meningkatkan kualitas manajemen dan tata kelola keuangan sehingga dapat menciptakan UMKM yang mandiri. Kegiatan ini dilakukan melalui tiga tahap yaitu perencanaan, pelaksanaan dan evaluasi. Kegiatan pelatihan ini dilaksanakan dalam dua kali pertemuan yang dihadiri oleh 25 peserta dari pelaku UMKM di lingkungan PKK Tiban Global. Berdasarkan dari hasil dan pembahasan pada kegiatan ini, pelaku UMKM dibekali tentang pendidikan kewirausahaan, strategi pemasaran yang efektif dan pengelolaan keuangan sederhana serta mengenali berbagai skema pembiayaan yang dapat dimanfaatkan oleh pelaku UMKM. Pelatihan ini memberikan pemahaman dan perbaikan bagi pelaku UMKM dalam pengelolaan usahanya, beberapa perbaikan yang bisa dilakukan para UMKM yaitu perbaikan karakter dalam menjalankan usahanya, karena para UMKM selalu dihadapkan dengan tantangan baru seperti perkembangan teknologi, munculnya usaha baru yang secara langsung maupun tidak langsung dapat berpengaruh pada jalannya usaha, merencanakan dan mengatur keuangan usaha dengan tepat, pemasaran yang lebih efektif dengan penggunaan sosial media dan iklan berbayar seperti instagram ads maupun facebook ads, perbaikan berikutnya yaitu akses permodalan yang bisa didapatkan oleh pelaku UMKM melalui lembaga-lembaga yang ditunjuk dalam pengalokasian dana bagi pelaku UMKM.
\end{abstract}

Kata Kunci: Kewirausahaan, Manajemen, Tata Kelola, Keuangan, Pemasaran

\section{ABSTRACT}

In order to support government programs in creating entrepreneurship and supporting the improvement of the quality of MSMEs, the Management Study Program will provide training to MSMEs who are in the PKK Tiban Global environment. This training aims to 


\section{JURNAL ABDIMAS BSI}

Jurnal Pengabdian Kepada Masyarakat

improve entrepreneurship and improve the quality of management and financial governance so as to create MSMEs independent. This activity is carried out through three stages, namely planning, implementation and evaluation. This training activity was held in two meetings attended by 25 participants from MSMEs in the PKK Tiban Global environment. Based on the results and discussion on this activity, MSMEs are provided about entrepreneurship education, effective marketing strategies and financial management and recognize various financing schemes that can be utilized by MSMEs. This training provides understanding and improvement for MSMEs in managing their businesses, several improvements that can be made by MSMEs, namely improving character in running their business, because MSMEs are always faced with new challenges such as technological developments, the emergence of new businesses that can directly or indirectly influence of the business, plan and manage business finance appropriately, more effective marketing with the use of social media and paid advertisements such as instagram ads and facebook ads, the next improvement is access to capital that can be obtained by MSMEs through the institutions designated in allocating funds for MSMEs.

Keywords: Entrepreneurship, Management, Governance, Finance, Marketing

\section{Pendahuluan}

Salah satu kekuatan ekonomi yang selama ini telah terbukti kehandalannya dalam menunjang ekonomi negara Indonesia dan kekuatan ekonomi daerah adalah kehadiran pelaku usaha kecil yang sering disebut UMKM (usaha kecil dan menengah). Terlebih disaat ekonomi dunia dan perekonomian negara Indonesia mengalami resesi, justru pelaku UMKM sedikitpun tidak menampakkan gejala atau efek negatif resesi ekonomi tersebut, bahkan sebagian besar pelaku UMKM tetap eksis dalam kegiatan usahanya dalam menunjang perekonomian negara kita.

Hal ini sudah diakui ketangguhannya melalui kegiatan seminar, lokakarya bahkan kegiatan ilmiah lain di bidang akademisi. Peran industri kecil yang didalamnya terdapat pelaku UMKM tidak kecil dalam mempertahankan dan meningkatkan kontribusi pertumbuhan ekonomi daerah. Uniknya peningkatan penerimaan sektor pajak negara, selain ditunjang oleh industri skala besar, juga ditunjang secara signifikan oleh kelompok-kelompok industri skala kecil tempat pelaku UMKM bernaung.

UMKM berperan sebagai sumber pendapatan bagi masyarakat, pemenuhan barang dan jasa, penciptaan lapangan pekerjaan, serta peningkatan nilai tambah sehingga menurunan angka kemiskinan dan pertumbuhan ekonomi. Potensi yang ada pada UMKM ke depan menurut data dari Asian Development Bank (ADB) Institute pada tahun 2015 Indonesia menjadi negara yang memiliki kontribusi UMKM yang paling besar terhadap PDB 57,8\% dan penyerapan tenaga kerja 97,2 \%, serta ekspor 15,8\% sebagaimana terlihat pada Gambar 1. 
Jurnal Pengabdian Kepada Masyarakat
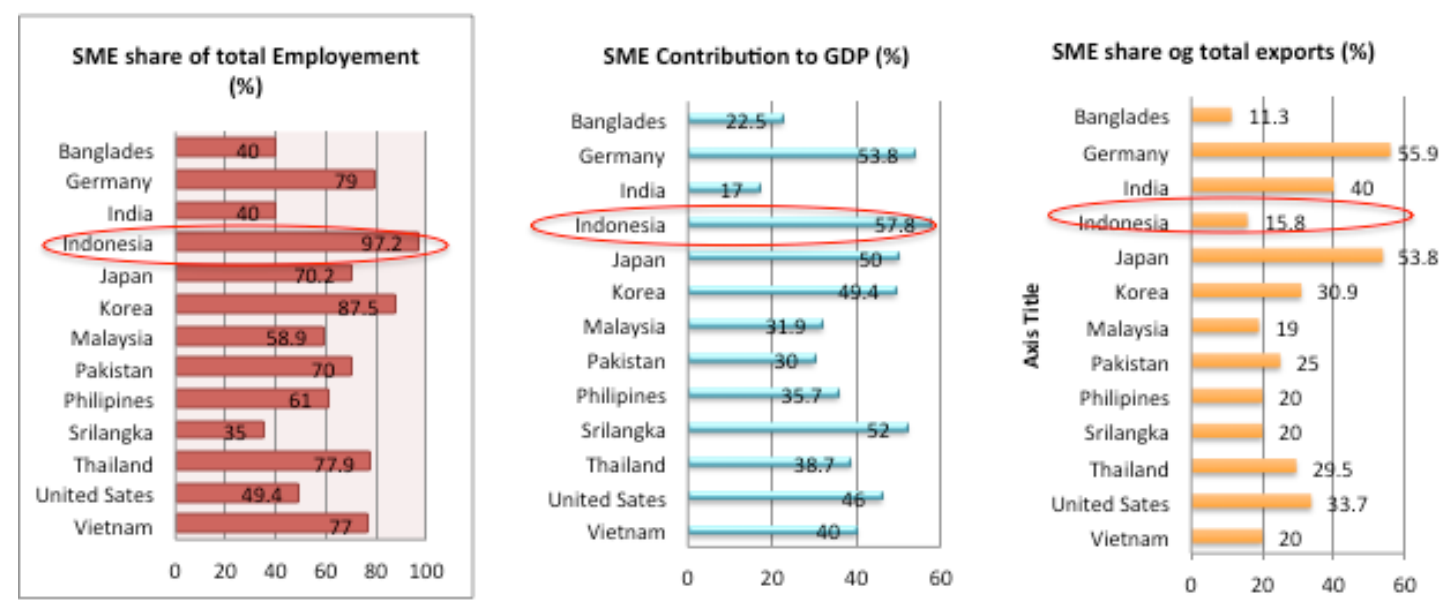

\section{Gambar 1}

\section{SME Share Of Employment, Export And Contribution To GDP}

Kementerian Koperasi dan Usaha Kecil Menengah (UMKM) melihat kontribusi sektor UMKM mengalami peningkatan dari 57,84 persen menjadi 60,34 persen dan sektor UMKM juga telah membantu penyerapan tenaga kerja di dalam negeri. Penyerapan tenaga kerja pada UMKM mengalami peningkatan dari yang sebelumnya sebesar 96,99 persen, saat ini menjadi 97,22 persen dalam lima tahun terakhir .(Kemenperin, 2016). Dengan total sekitar 57 juta UMKM yang ada di Indonesia, maka akan berdampak pada pertumbuhan ekonomi di Indonesia.

Berbagai program telah dilaksanakan oleh Pemerintah untuk memajukan dan mendorong UMKM dan terbukti dari hasil survey Asean SME Policy Index (2014) Indonesia memiliki indeks sebesar 4.1. Hal ini menunjukkan bahwa pemerintah Indonesia memiliki kinerja cukup baik dibandingkan dengan negara-negera lain dalam menerapkan berbagai kebijakan tentang pengembangan UMKM.

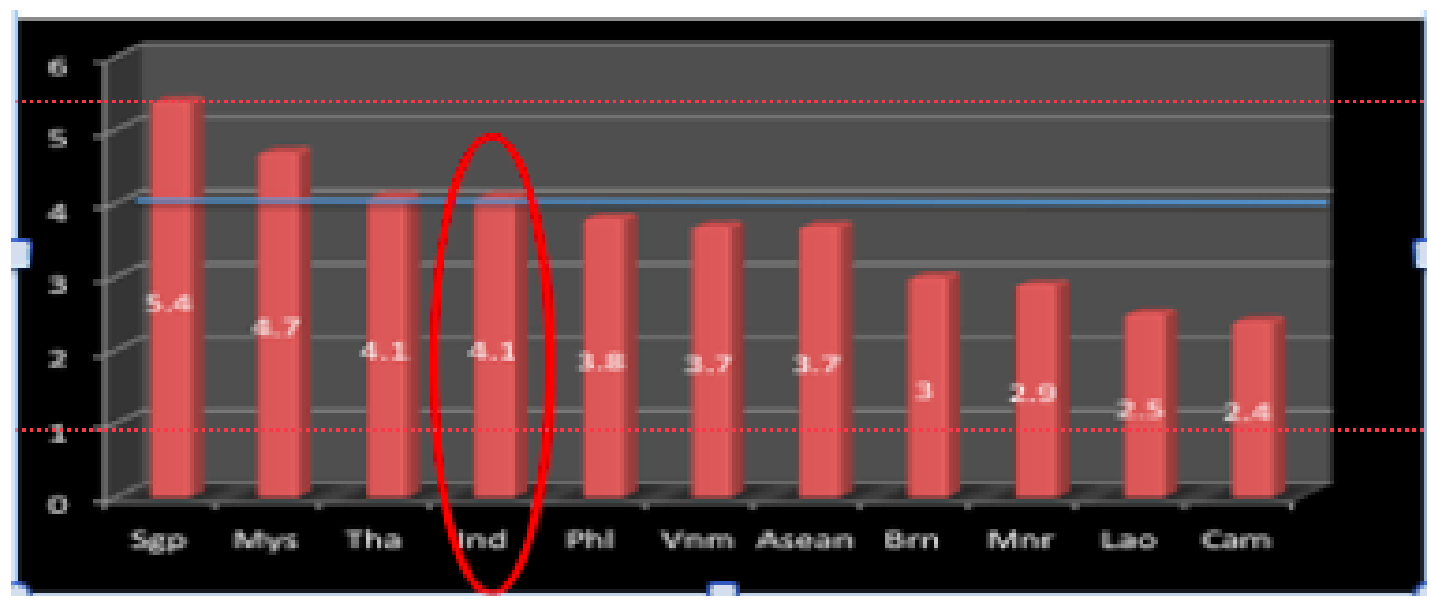

Gambar 2.

ASEAN SME Index Policy 2014 
Pemerintah telah mendukung dengan berbagai kebiajakan sehingga memudahkan bagi para UMKM untuk mengembangkan potensi pasarnya. Beberapa hal perlu mendapatkan perhatian dalam upaya pengembangan UMKM yaitu peningkatan kualitas manajemen dan pemahaman tentang penerapan teknologi serta pengelolaan keuangan (Komalasari, 2016).

Prospek pada para pelaku UMKM di Era Perdagangan Bebas akan menciptakan tantangan nyata yang harus dihadapi dengan baik dan apabila tidak terselesaikan maka akan menjadi ancaman di kemudian hari. Globalisasi mendorong perekonomian dunia dalam menghadapi ketidakpastian terutama pada tingginya mobilisasi sumber daya produksi serta investasi pada berbagai sector di setiap negara akan menjadi gejolak di berbagai negara.

Permasalahan tersebut menjadi sesuai yang harus diselesaikan pada UMKM di Indonesia dalamperubahan yang ada. Untuk itu perlu dipahami terlebih dahulu keberadaan UMKM di Indonesia. .Para UMKM memiliki berbagai permasalahan selain dari sisi modal ternyata para UMKM terkendala masalah manajerial, bagaimana memimpin organisasi dan bagaimana mengembangkan usahanya seehingga dapat bertahan di pasar kemudian para UMKM juga terkendala dalam mengelola laporan keuangan. Maka ini menjadikan bahan pertimbangan untuk melakukan pengabdian masyarakat.

Potensi UMKM hingga sejauh ini, belum cukup tergarap dengan maksimal, sebaliknya banyak pelaku kegiatan UMKM (pemilik) justru sering mengalami masalah internal sehingga sulit untuk berkembang dan bersaing baik antara sesama UMKM maupun dengan dengan produsen besar. Masalah pengelolaan keuangan merupakan salah satu masalah yang sering ditemui di dalam UMKM. Umumnya, pelaku kegiatan UMKM memulai usaha mereka dengan bermodal nekat tanpa dibekali dengan rencana pemodalan jangka panjang maupun kemampuan dan pengetahuan manajerial yang dibutuhkan dalam berwirausaha. Beberapa masalah pengelolaan keuangan umum yang sering dijumpai pada UMKM antara lain adalah:

1. Kemampuan manajerial, keberanian dalam mengambil keputusan dan mengkalkulasi resiko

2. Pemasaran yang masih kurang efektif

3. Belum memiliki perencanaan strategis

4. Masih tercampurnya keuangan pribadi pemilik dengan keuangan usaha

5. Penentuan harga produk sering dilakukan secara sederhana dan intuitif, tanpa menghitung biaya yang telah dikeluarkan secara cermat

6. Buruknya metode pencatatan transaksi yang dilakukan

7. Kurangnya pengetahuan mengenai pencatatan keuangan dan pengelolaan keuangan (akuntansi)

Pelatihan ini bertujuan untuk pemahaman dan perbaikan bagi pelaku UMKM melalui pendidikan karakter yang diperlukan dalam menghadapi tantangan usaha saat ini, kemudian perbaikan dalam hal pengelolaan keuangan yang standar, pelatihan ini juga membekali para pelaku UMKM dengan startegi pemasaran digital, 
seperti penggunaan media sosial dan paid advertising, sehingga pemasaran yang dilakukan bagi pelaku UMKM lebih efektif.

\section{Metode}

Uraian metode pelaksanaan adalah dengan metode lesson study yang pelaksanaannya sama dengan penelitian tindakan kelas dengan tiga tahapan:

a) Tahap I : Perencanaan (Planning)

Perencanaan dimulai dengan komunikasi dan koordinasi dengan pihak mitra yaitu ketua RT Tiban Global dan para UMKM, kami akan memaparkan rencana pelaksanaan program pengabdian kepada masyarakat ini sekaligus mengkoordinasikan waktu dan tempat pelaksanaan, metode pelatihan, jumlah peserta, bahan-bahan dan peralatan yang dibutuhkan. Hal ini dilakukan sampai semua aspek sudah benar-benar siap sampai tahap pelaksanaan sehingga tidak ada lagi penghalang-penghalang atau hambatan yang berhubungan dengan persiapan. Pada tahap ini diharapkan juga sudah ada koordinasi yang baik antara tim dengan mitra.

b) Tahap II : Pelaksanaan

Tahap ini dibagi menjadi beberapa kegiatan:

- Pemaparan: pada saat pemaparan, tim akan memaparkan hal-hal umum mengenai kewirausahaan, kemampuan manajerial dan tata kelola keuangan.

- Pelatihan: Pelatihan ini diharapkan akan memberi pengetahuan dan dapat diimplementasikan oleh para UMKM sehingga nantinya dapat meningkatkan daya saing bagi para pelaku UMKM di lingkunagn PKK Tiban Global.

c) Tahap III : Refleksi

Tahap ini diharapkan para peserta mitra dapat mengelola manajemen usahanya dan mengelola laporan keuangannya sehingga ppara UMKM dapat meningkatkan daya saing.. Hal ini dapat dilakukan dengan beberapa cara:

- Meminta mereka untuk mengisi kuesioner mengenai manfaat pelatihan berikut dengan saran sebagai bentuk umpan balik (feed back) dari mitra

- Memberikan mereka kesempatan untuk praktik membuat laporan keuangan dan penentuan harga produk.

\section{Hasil dan Pembahasan}

Kegiatan pengabdian masyarakat pada UMKM di lingkungan PKK Tiban Global dilakukan dua kali berupa pelatihan dan pendampingan. Kegiatan ini dihadiri 25 orang yang terdiri dari berbagai pelaku UMKM yang ada di lingkungan Tiban global. Beberapa kategori usaha yang dijalankan antara lain makanan dan minuman, pakaian, industri kreatif dan hidroponik. 


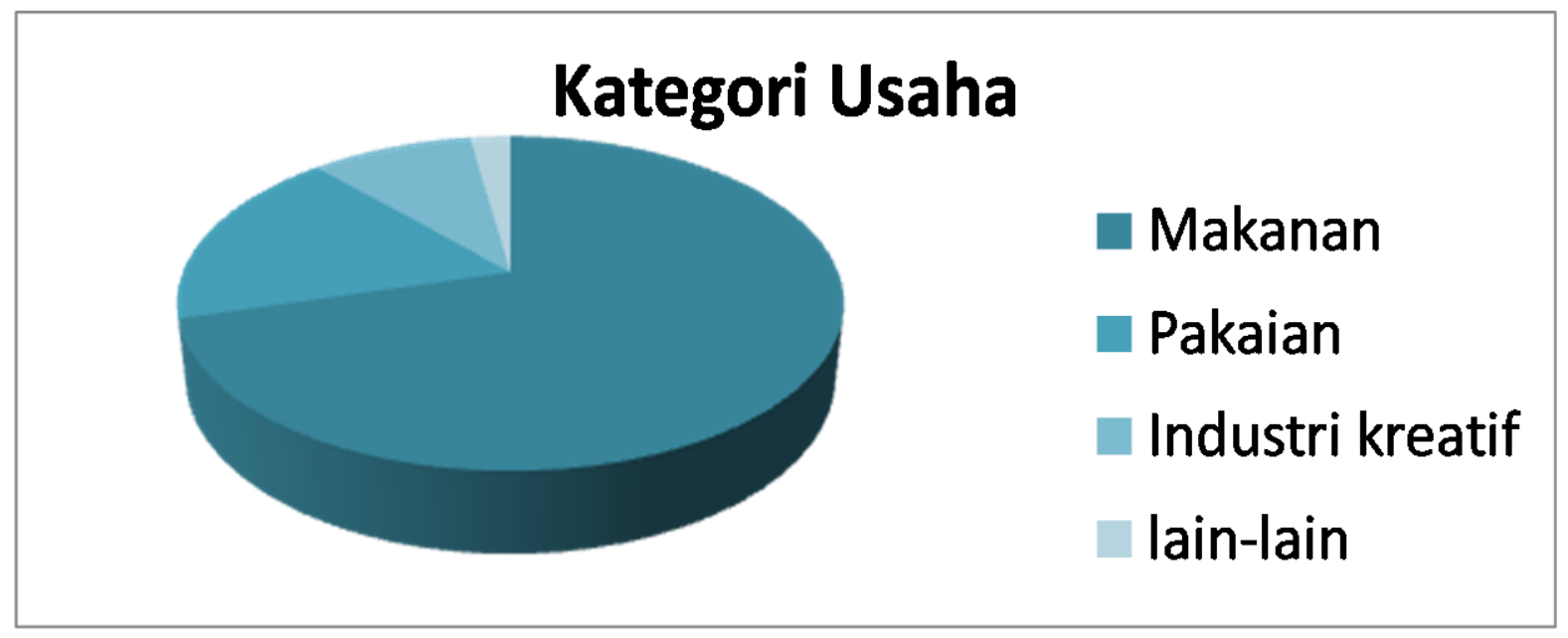

Gambar 3

Kategori Usaha

Pada kegiatan pertama pelatihan mencakup pemahaman mengenai womenpreneur, peranan wanita bukan hanya sebagai ibu rumah tangga namun juga dapat menjadi produktif dengan menjadi wirausaha. Saat ini terdapat tiga kelompok utama yang sangat berpengaruh yaitu women, youth dan netizen (Kartajaya, 2014). Pelatihan ini memberikan pemahaman kepada UMKM di lingkungan PKK Tiban Global mengenai pemahaman mengenai wirausaha dan juga membangun entrepreneurial spirit. Menurut Ciputra (2011) entrepreneurial spirit terdiri dari minat (passion), mandiri (independent), peka terhadap pasar (market sensitivity), mengkalkulasi resiko yang akan diambil (calculated risk taker), mampu berpikir kreatif dan inovatif (creative $\mathcal{E}$ innovative), gigih (persistence) dan memiliki etika dalam berwirausaha (high ethical standart).

Pelatihan selanjutnya membahas tentang hal teknis yang berhubungan dengan peningkatan kemmampuan berpromosi melalui social media. Para pelaku UMKM diajarkan mengnai cara efekktif dalam memasarkan produknya menggunakan social media. Pelatihan pada sesi ketiga membahas mengenai strategi pemasaran yang efektif mulai dari memberikan nama merek yang menarik sehingga mudah di ingat oleh konsumen serta memberikan pemahaman bagi pelaku UMKM untuk membuat kemasan yang sesuai standar, dengan kemasan yang baik maka akan membuat kualitas dari produk terjaga dan membuat daya tarik bagi para konsumen.

Pelatihan pada hari kedua membahas tentang teknis pengelola keuangan bagp para pelau UMKM. Pelatihan pertama membahas mengenai pembuat laporan sederhana bagi pelaku UMKM skala SAKETAP (Standar Akuntansi Keuangan untuk Entitas tanpa Akuntabilitas Publik). Laporan Keuangan merupakan hal terpenting dalam menjalankan suatu usaha baik yang berskala mikro, kecil, menengah maupun yang berskala besar, dimana melalui laporan keuangan yang benar, akurat dan berstandar, informasi secara lengkap mengenai suatu usaha dapat diketahui dan dinilai secara jelas, dari laporan keuangan juga berfungsi sebagai sumber informasi 


\section{JURNAL ABDIMAS BSI}

Jurnal Pengabdian Kepada Masyarakat

dalam membuat kebijakan dan keputusan guna menanggapi persaiangan usaha maupun dalam rencana pengembangan suatu usaha yang dijalankan.

\section{Tabel 5}

Jadwal dan Waktu Pelaksanaan

\begin{tabular}{|c|c|c|c|}
\hline $\begin{array}{c}\text { Pelaksanaan } \\
\text { Kegiatan }\end{array}$ & Materi & Alat dan Bahan & Waktu \\
\hline Hari 1 & $\begin{array}{l}\text { 1. Womenpreuneur (Membangun } \\
\text { Enterpreneurial Spirit) } \\
\text { 2. The power of social media } \\
\text { marketing } \\
\text { 3. Strategi pemasaran produk usaha } \\
\text { mikro kecil dan menengah }\end{array}$ & $\begin{array}{l}\text { LCD proyektor, laptop, } \\
\text { internet, sound system }\end{array}$ & $\begin{array}{l}\text { 1. } 90 \text { menit } \\
\text { 2. } 90 \text { menit } \\
\text { 3. } 90 \text { menit }\end{array}$ \\
\hline Hari 2 & $\begin{array}{l}\text { 1. Laporan keuangan sederhana } \\
\text { untuk UMKM Skala SAKETAP } \\
\text { (Standar Akuntansi Keuangan } \\
\text { untuk Entitas tanpa Akuntabilitas } \\
\text { Publik) } \\
\text { 2. Konsep dan aplikasi pembiayaan }\end{array}$ & & 1. 90 menit \\
\hline
\end{tabular}

Sebagai bentuk pertanggungjawaban pelaku usaha kepada negara dalam hal perpajakan, laporan keuangan merupakan salah satu item penting yang dibutuhkan, selain itu laporan keuangan juga merupakan suatu keharusan bagi pelaku usaha saat membutuhkan dana sebagai tambahan modal perluasan usaha kepada pihak perbankan, jadi pembuatan dan penyediaan laporan keuangan secara baik dan akurat bagi pelaku usaha baik berskala mikro, kecil, menengah maupun yang berskala besar adalah bersifat keharusan.

Dalam pelatihan ini dihadiri oleh 25 UMKM yang ada di wilayah PKK Tiban Global. Pelatihan ini menitikberatkan pada peningkatan kualitas manajemen dan tata kelola keuangan, diharapkan dengan pelatihan ini para pelaku UMKM terus memperbaiki kualitas produksi, proses pemasaran hingga membuat laporan keuangan dengan baik. Pelatihan pada hari pertama menekankan pada pembentukan entrepreneurial spirit dan peranan perempuan sebagai womenpreneur maupun ibu rumah tangga.

Pelaku UMKM yang juga merupakan ibu rumah tangga perlu membagi waktu antara keluarga dan pekerjaan. Peserta diharapkan dapat menyerap materi yang nantinya dapat mengaplikasikan jiwa wirausaha (entrepreneurial spirit) dan pola pikir wirausaha (entrepreneurial mindset) sehingga peserta mampu untuk mengkalkulasi resiko yang ada, berpikir kreatif dan peka terhadap pasar serta membangun bisnis yang didasari dengan etika (Febriyantoro, 2018). Pelaku UMKM juga mempelajari penggunaan media sosial yang tepat untuk memasarkan produknya. Penggunaan media sosial seperti facebook, twitter, instagram dan lain sebagainya akan memudahkan konsumen ketika mencari produk yang mereka inginkan 
(Febriyantoro \& Arisandi, 2018). Pemateri mengajarkan para peserta membuat facebook page yang tujuannya agar produk dari pelaku UMKM di wilayah Tiban Global dapat menyebar luas dan tepat sasaran, terutama penggunaan hastag di setiap posting yang dilakukan di media sosial. Selain itu para pelaku UMKM juga diajarkan untuk membuat desain kemasan dan logo yang menarik, sehingga dapat menarik atensi dari konsumen dan dampaknya mengarah pada penjualan produk tersebut (Febriyantoro, 2016).

Pada sesi berikutnya para pelaku UMKM mendapatkan pemahaman mengenai pengelolaan pemasaran yaitu pemilihan merek (brand) yang mudah di ingat serta memperhatikan kemasan yang bertujuan untuk menjaga kualitas produk dan membuat daya tarik bagi konsumennya.

Pada hari kedua pelatihan menitikberatkan pada tata kelola keuangan bagi para pelaku UMKM di wilayah Tiban Global. Pada sesi pertama pada hari kedua peserta diajarkan tentang pembuatan laporan keuangan yang terdiri dari neraca, laporan laba rugi, laporan perubahan ekuitas, laporan arus kas dan catatan atas laporan keuangan. Diharapkan dengan laporan pembekalan mengenai pembuatan laporan keuangan sederhana para pelaku UMKM dapat mengelola keuangannya dengan baik dan memisahkan anggaran pribadi dan anggaran perusahaan.

Pada sesi terakhir peserta diberi pemahaman mengenai konsep dan aplikasi pembiayaan pada UMKM. Pelaku UMKM di wilayah Tiban Global sering mengalami masalah dalam hal pendanaan, hal ini di picu karena ketidaktahuan dari peserta dalam mencari modal pembiayaan bagi usahanya. Pelatihan ini memberikan wawasan kepada para pelaku UMKM dalam mencari pembiayaan usaha bisa dari berbagai pihak bukan hanya dari perbankan saja namun pelaku UMKM dapat mengajukan pendanaan dari beberapa pihak antara lain dana pendampingan usaha dari kementerian terkait, program penguatan usaha kecil dari DIPA Pemerintah Daerah, dana PKBL BUMN, fasilitas dari Perguruan Tinggi, LSM, Koperasi, Asosiasi Usaha dan lain sebagainya.
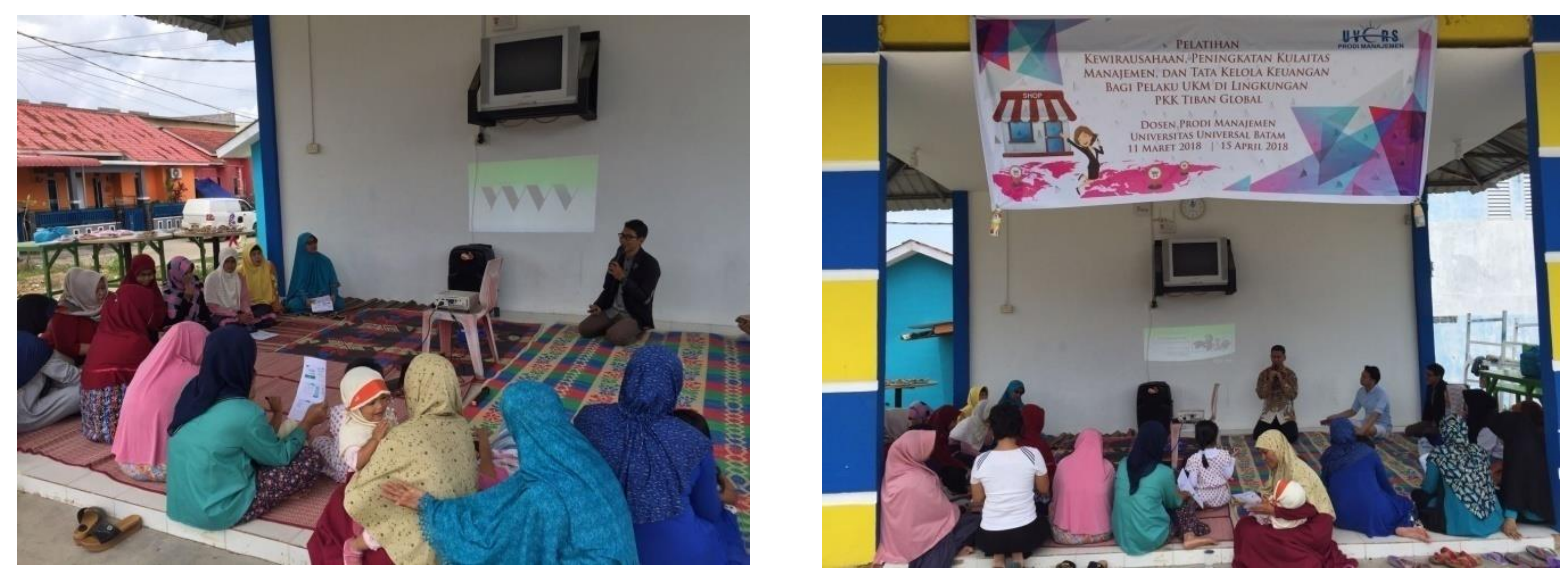

Gambar 4.

Dokumentasi Pelatihan pada UMKM di lingkungan PKK Tiban Global 


\section{JURNAL ABDIMAS BSI}

Jurnal Pengabdian Kepada Masyarakat

\section{Simpulan dan Saran}

Kegiatan ini bermanfaat bagi para pelaku UMKM guna meningkatkan kemampuan manajerial dan tata kelola keuangan. Para peserta diharapkan memiliki entrepreneurial spirit dan entrepreneurial mindset serta membagi peran antara keluarga dan usaha. Kemudian para peserta mampu mengaplikasikan pemasaran yang efektif dengan penggunaan social media dan social chatting untuk promosi produknya dan memberikan nama merek yang mudah di ingat serta menjaga kualitas produk dengan membuat kemasan yang sesuai dengan standar.

Dengan adanya pelatihan ini para UMKM dapat membuat laporan keuangan yang baik dan benar serta memahami prosedur dalam program yang dikeluarkan oleh berbagai pihak dalam proses pendanaan dan pembiayaan bagi pelaku UMKM.

Pelatihan ini nantinya dapat berlanjut sehingga proses kownledge transfer dapat berjalan dengan baik dan pelaku UMKM bukan hanya di lingkungan Tiban Global saja melainkan dapat menjangkau seluruh UMKM yang ada di wilayah Kota Batam.

\section{Daftar Pustaka}

ASEAN Policy Index. (2014). ASEAN Policy Index. Retrieved September 18, 2018, from http:/ / www.eria.org/Key_Report_FY2012_No.8_prologue.pdf

Ciputra. (2011). Ciputra Quantum Leap 2. Jakarta: Elex Media Komputindo.

CNN Indonesia. (2016). Kontribusi UMKM Terhadap PDB Tembus Lebih Dari 60 Persen. Retrieved May 20, 2017, from http:/ / www.cnnindonesia.com/ekonomi/20161121122525-92-

174080/kontribusi-umkm-terhadap-pdb-tembus-lebih-dari-60-persen/

Febriyantoro, M. T. (2016). Pemikiran irasional para perokok. EKSIS, XI(2), 19077513.

Febriyantoro, M. T. (2018). The Role Of Entrepreneurial Campus In Establishing Of Students' Entrepreneurial Mindset and Entrepreneurial Spirit. International Conference of Econimic Studies, 141-146.

Febriyantoro, M. T., \& Arisandi, D. (2018). Pemanfaatan Digital Marketing Bagi Usaha Mikro, Kecil Dan Menengah Pada Era Masyarakat Ekonomi Asean, 1(2), 61-76.

Kartajaya, H. (2014). Wow Marketing (1st ed.). Jakarta: Gramedia Pustaka Utama.

Komalasari, L. (2016). Problem UMKM Dalam Pengembangan Usaha: Studi Pada UMKM di Desa Mulyoarjo, Malang. Jurnal Sospol, 2(2). 